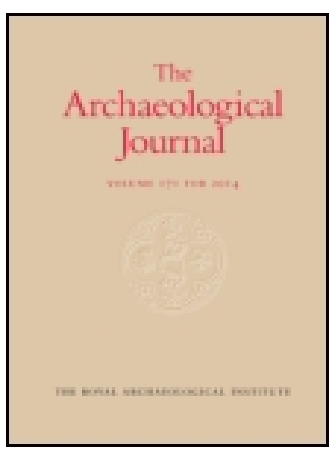

Archaeological Journal

\title{
Notices of Architectural Remains in Brecknockshire
}

\section{H. S. Davis Major, 52nd Regt. Lt. Inf.}

To cite this article: H. S. Davis Major, 52nd Regt. Lt. Inf. (1850) Notices of Architectural Remains in Brecknockshire, Archaeological Journal, 7:1, 26-33, DOI: 10.1080/00665983.1850.10850767

To link to this article: http://dx.doi.org/10.1080/00665983.1850.10850767

曲 Published online: 06 Dec 2014.

Submit your article to this journal $\asymp$

Q View related articles $\sqsubset$ 
THE following remarks were made during a residence of some months at Brecon, in South Wales. They are put together for the purpose of illustrating the accompanying representations of the remains of ecclesiastical architecture in that place.

My object is to bring these interesting remains to the notice of the Archaeological Institute; in hope that this notice may have the effect of bringing the existence and actual state of the remains to which it refers, to the consideration of the Society, in order that, if possible, such venerable relics may be preserved from further ruin and mutilation.

The town of Brecon, or Brecknock, as the inhabitants always call it, is delightfully situated on the junction of the IIondy (or Black River), with the river Usk. Brecon, from all that has been ascertained, can claim no greater antiquity than the middle of the eleventh century, the more ancient town having been three miles higher up the Usk, at Caervannau (which had by some been supposed to be the Bannium of the Romans ${ }^{1}$ ), which was destroyed by Bernard Newmarch, the Norman, who, not liking the situation, carried all the materials of the town of Caer-leon, which he had conquered, to the junction of the Hondy with the Usk, where he built a castle, round which those persons driven from Caer-vannau, and who were content to remain his followers for protection and other sufficient reasons, soon gathered, and this, by Johnes's account, is supposed to have been the origin of the present town. It was soon after this time that the walls and ten towers (some of which are still remaining, and originally surrounded the town) were built. Leland describes the castle as being very large, and having ten towers in the circuit of the wall, and a ditch, into which the waters of the Hondy could at pleasure, and for defence, be poured.

Bernard Newmarch is believed to have founded the Benedictine Priory at Brecon, ${ }^{2}$ which was a cell to Battle Abbey

1 "Bannio" of the Chorographia, is explained by Horsley as identical with Gobannium, Abergavenny, pp. 491,504 . See notices of Roman remains near Brecon,
Archaeologia, vols. i., p. 295., vii., 209.

2 Leland, Itin., vol. v., fol. 68 . See a detailed account of this foundation, Mon. Angl., new edit, vol. iii., p. 259. 


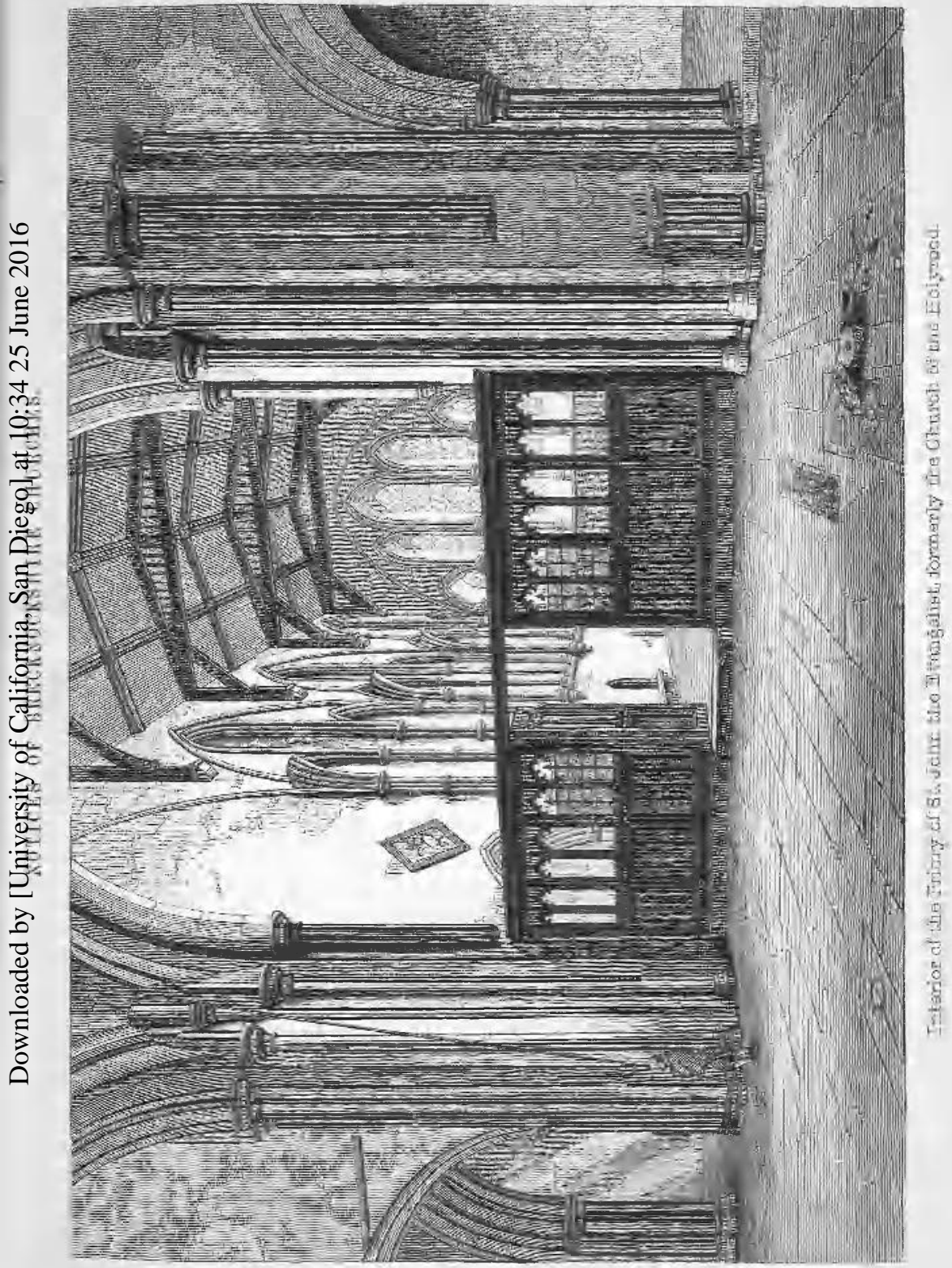


about the close of the eleventh century. The church was called "Ecclesia Sanctæ Crucis" (the Church of the Holy Rood). The accompanying illustration (Pl. I. A.) shows the whole length of the Priory church, viewed from the north side. It is a most imposing mass of building, comprising a nave, with aisles, a chancel, and north and south transepts, each of which have aisles on their eastern sides, and communicate by deep moulded Early English arches with the chancel, but these have been for some years blocked up by the monuments of the Camden family. The remains of a chapel, unroofed, with an altar-window and piscina, on the south side of the great chancel, are visible; the entrance being by a small door. The chancel and nave have at their entrances under the intersection of the transepts beneath the great tower, finely worked open screens of the Decorated period. The interior of the chancel deserves especial attention, from the beauty, delicacy, and fine finish of the masonry. It is lighted by lancet windows, on each side, of great height, which, splaying inwards, are separated by three detached slender and banded Early English shafts, supporting the commencement of a groined roof, which it appears was never finished. The east window is a combination of lancets.

The length of the nave of this church is 136 feet; the breadth, 28 feet. On the east side of the north transept, the chapel or aisle is called "Battle," or "Capel y Cochiaid," "Chapel of the Red-haired Men, or Normans." It is 38 feet long, and 29 feet wide, and has in it a very curious slab, mentioned by Johnes in his "History of Brecknockshire." It exhibits two figures recumbent, one holding a cross on the breast, and angels swinging censers above them. Nearly the whole of the transept and chancel are paved with large monumental slabs, ornamented with highly floriated crosses ; many exhibit the badges of ancient guilds, as old, it is supposed, as the times of the Edwards. Five chapels in the nave are designated as follows : the Weavers', Tuckers', Tailors', Corvisors' (Shoemakers), Glovers' or Skinners' ; and at a remote period these guilds had probably their different halls for meeting for the settlement of their affairs. Little remains now of the monastery attached to this church : the stables of Lord Camden's residence appear to have formed either a refectory or a dormitory, of considerable size. Some large lavatories remain, and a tomb, said to 
be that of Bernard Newmarch, which stood under the great tower, was pulled down, and converted by the old women of Brecon into means for scrubbing their tubs and milk-pails. The transepts are Early English, and very imposing; the nave and aisles of much later date ; the original font, probably the gift of the founders of the Abbey, is at the west end of the nave, and it is a very fine specimen, but mounted on a barbarous modern base. (See woodcut.) It appears older than anything that surrounds it. Near the altar in the chancel is a remarkable slab, in very high relief, of about four inches, surrounded with a deep projecting moulding of the same depth. The subject is a rood, with figures of souls in purgatory, beneath. The Priory was called "The Church of the Holy Rood," and this slab, which, from its relief, appears not suited to have been a monumental pavement stone, may, possibly, I think, have been gilt and coloured, forming a portion of the reredos to the high altar, to which it now lies adjacent. The nave is used on Sundays for Divine Service, and the Holy Communion is always administered in the chancel. This structure is worthy of careful inspection, and in general interest may compare with some of the finest architectural remains in the United Kingdom. (See the annexed illustration.)

Perhaps as interesting, though not so extensive, remains are to be seen on a visit to Christ's College, on the opposite and right bank of the Usk.

\section{CHRIST'S COLLEGE, BRECKNOCK,}

Is supposed to have been originally a monastery of Black Friars, lay and clerical, and to have been dedicated to St. Nicholas. ${ }^{3}$ Little of its early history is known, and none of the names of the Priors previous to the reign of Henry VIII., except one,-Richard David. There is reason, however, to believe, as stated in Johnes's "History of Brecon," that Thomas Beck, Bishop of St. David's in 1283, intended to commence a foundation of a similar character, at Llangador, in Caermarthenshire, under the invocation of St. Maurice. His intention, however, appears to have failed, and his suc-

3 Christ's College is stated to have been formerly at Abergwylli, and was removed in Henry VIII.'s time to Brecon, See Monast. Angl., new edit., vol. vi., p. 1496. 
ARCHITECTURAL NOTICES, BRECKNOCKSHIRE.

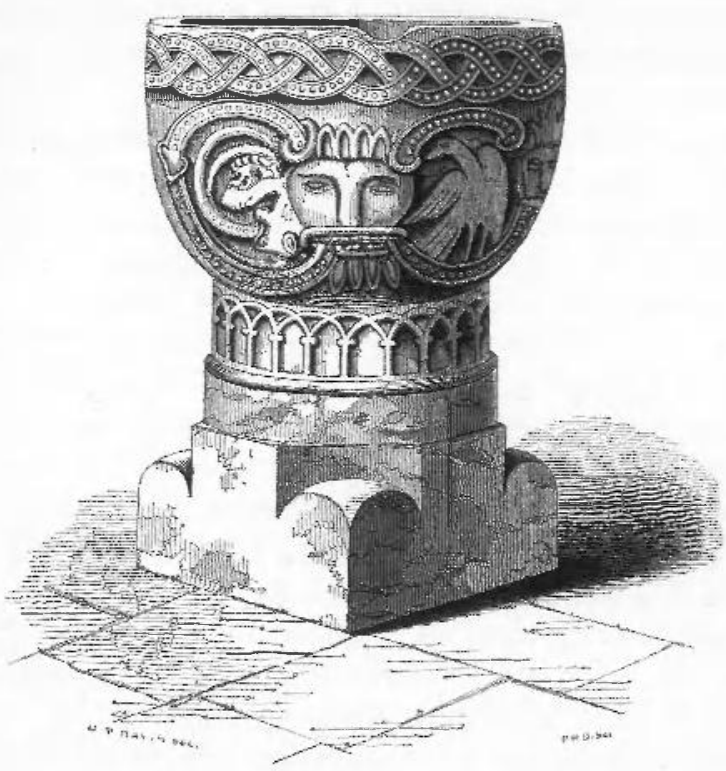

Norman Font, in the Priory Church, Brecon. 
cessor, Henry de Gower, revived his project, but instead of Llangador, Abergwylli Church was made Collegiate, and remained so until 1531. It was originally dedicated to St. Maurice and his companions, and to the blessed St. Thomas, the Martyr of Christ, " and consisted of twenty-one canons, to serve God day and night, worthily and devoutly, in the same manner as was done at St. David's, like which place they were to be in all respects, except their amices, which at St. David's were purple, in honour of St. Maurice, who was beheaded, but theirs were to be of goat or lamb skin, for the sake of economy." Five clerks of inferior degree were ordained, "two to carry censers, two to carry each a candle, and the fifth a cross in processions, and to have fifty shillings equally divided amongst them yearly." We hear nothing more until some years after this, when a bishop of St. David's, becoming possessed of the land, goods, and chattels of the House of Abergwylli, was empowered to appoint a schoolmaster and lecturer at a salary of $52 l$. per annum. This foundation however (it appears from Johnes's account, who was DeputyRegistrar of the Archdeaconry of Brecon), was translated from Abergwylli to Brecon by Bishop Lucy, by charter, 32 Henry VIII., in 1531. It appears to have been subject to many reverses, for, soon after, its possessors were engaged in a suit in Chancery, respecting their rights of possession, in which many witnesses were examined, whose depositions Johnes laments are not extant, as they might have thrown light on the circumstances relating to the foundation of this establishment, which is lost in obscurity. The prebendaries, after much expense, remained in quiet possession of their revenues, the Bishop occasionally residing, until the time of Charles I., when the Puritans seized the plate, ornaments, vestments, and the church, of which the chancel alone remains. Two of the piers belonging to the nave, may be seen against the west end of the small Sacristy Chapel, and the enclosure, there is no doubt, includes the space occupied by the nave destroyed by the Puritans when they robbed the place. In 1660, Bishop Lucy appears to have solicited the aid of all good Christians, in money, for the repairs of the church. In 1706, Bishop Bull was in residence, and he is buried near the altar.

The interior of the chancel or chapel, displays a most beautiful and imposing effect. On entering the west door (the only one), the interior is 66 feet in length, and 26 feet 
broad ; at the east end is a window of five lights, 63 feet in height; the north side is entirely occupied by an arcade composed of eleven lancet windows, which splaying inwards are separated from each other by one slender graceful Early English shaft, of great symmetry. (See woodcut, Pl. I. B.) On the south side, and facing the Bishop's Palace, are three windows corresponding with those opposite. The chapel is stalled with canopies ${ }^{4}$ of a late date, probably Bishop Lucy's ; they have the names of the dean and prebendaries, twentytwo in number, on their seats ; there is also a fine range of Sedilia, and a Piscina of Early English work, but sadly mutilated by cutting much away to make room for an unsightly tomb like a state bed of the eighteenth century.

The following list comprises the names of stalls, as they occur from right to left facing the altar :-

Right side.-Dom. Episcopus, Decanus, Cancellarius, Prebend of Trallwng, P. Llanwrthwl, P. Berglerood Llanbeden, Powis Castle, P. Llandilo Graban, P. St. Harman, P. Llanarthney, P. Llandwgwy, P. Lledrod, P. Llandegley.

Left side.-Precentor, Thesaurarius, P. Garthbleugg, P. Llanelwell, P. Cliron, P. Llangul, P. Llandisilio, P. Moogytrey, P. Llandryndod, P. Llandarog, P. Nantgunllo, P. Llansainthead.

The state of this chapel is most deplorable, and I cannot better describe it than by quoting the following interesting extract from Mr. Jesse's Tour in Wales.

"But there is one place at Brecon to which the wandering angler's attention should be directed. It is the interesting old Cathedral, now fast mouldering away, neglected, forsaken, and almost unknown. Who can see it without feelings of the deepest regret? No solemn anthem now ascends to Heaven, no choral praise is heard. The insidious ivy creeps through the roof, the floor is damp, and the old oak stalls with their curiously carved misereres are fast falling to decay. And why is this? Are there no funds to keep it in repair? No estates attached to its original foundation? Where is the dean who occupied the stall on which his name is inscribed, or the precentor or presbyters who sat in the others? Did they resign the ecclesiastical duties because decaying incomes kept pace with the decay of the sacred edifice? Nothing of

${ }^{4}$ Built by Bishop Lucy, Dean (1666) of Llandeau when the Archdeacon and Bishop of St. David's resided much in the Castle at that place. 


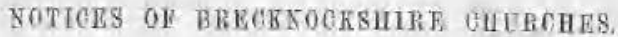

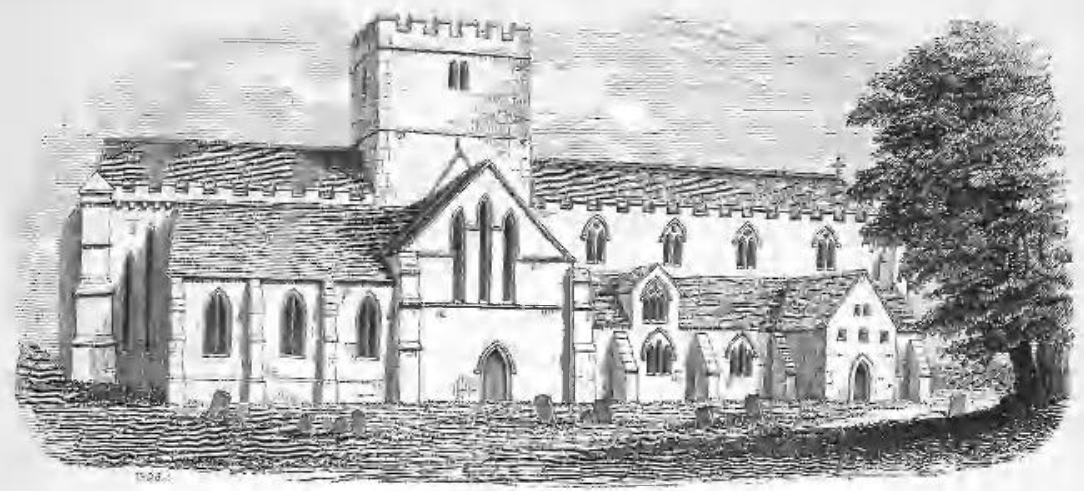

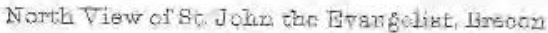

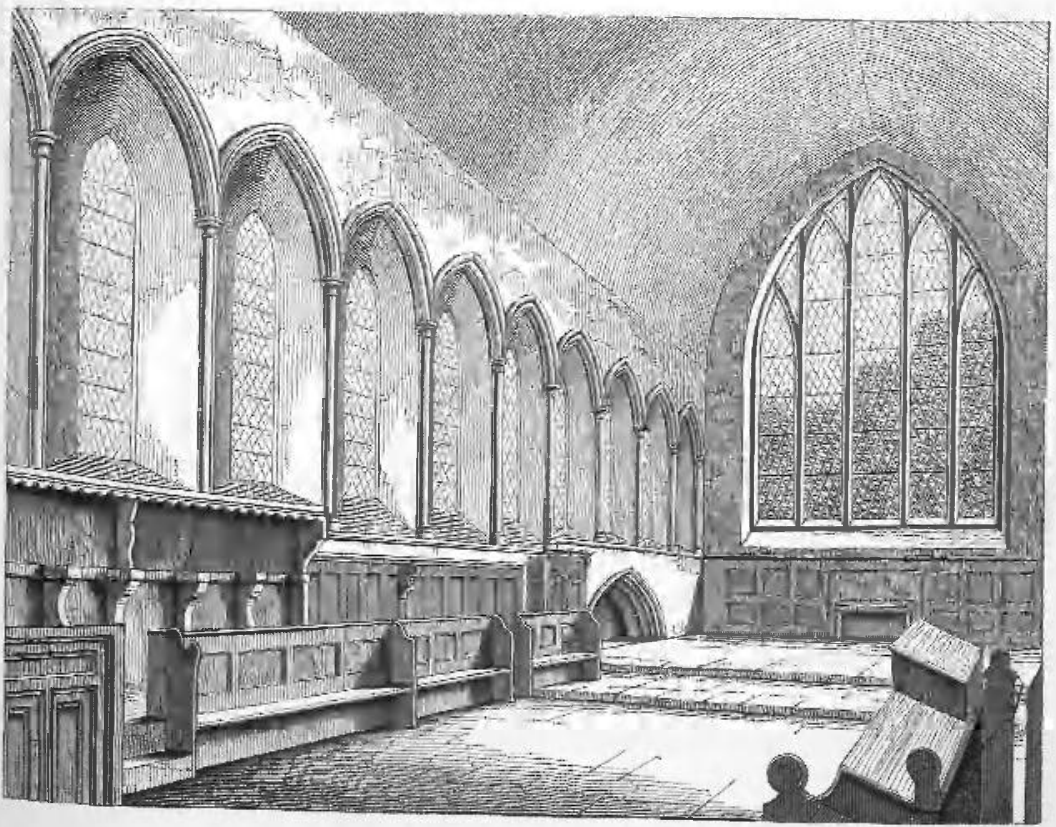

Interior of Christ's College Chapel, formerly Monastery of Black Eriars 
this sort is the case. The Bishop of St. David's is the dean, and there are no less than fifteen prebendaries, all of them (the Bishop included) deriving considerable incomes from this neglected place. It might have been thought that the monument of Dr. George Bull, that learned Bishop who did so much honour to his country and the Diocese to which he belonged, would have called forth some compunction, some regret, when the auditor paid the half-yearly incomes of these sinecurist churchmen, for the church they never visit nor uphold; and then the noble monument, one of the finest in England, of the Lucy family, and many others of great interest and antiquity, all are neglected, and subject to spoliation, for there was no one present to protect them when I entered the venerable sanctuary. Even the sexton, with his paltry salary of five pounds a year, has not received one farthing of it for many long years. Yet the estates flourish, the rents are paid, and the dean and prebendaries pocket the money. The livings which pious men left to this church are still held by them, and yet it is all decay, ruin, and desolation. If the good and excellent Archbishop of Canterbury should ever read these lines, let me hope that he will exert his powerful influence in protecting one of our earliest and most interesting churches from further neglect and desecration."

Thus ends the angler's story; the following fact may give some additional colour to Mr. Jesse's account. The author of this memoir was drawing on one occasion in the interior of Christ's College chapel, when a very abrupt knock was made at the west entrance, and on inquiring who was there, a stalwart drover said he wanted to drive in his sheep, in order that he might catch them, and that he had been in the habit of doing so on former occasions. He was reminded of the place being a sacred edifice, and that the key was in the custody of the person he was speaking to at the time, who could not countenance such desecration. The state of the stalls, on inspection, amply proved that his statement was correct.

The remains of the Bishop's Palace and Refectory are well worth notice, and they display a good specimen of the Early English period of architecture. There are in the gable, under the open old wooden roof, rooms which are said to have been the bishop's apartments; one of them has a trefoiled window in the gable, at the end, facing the College chapel; it is now inhabited by a respectable farmer, and is in 
general good repair. This interesting place is worthy of the best attention of archaeologists more especially, if they can by their influence aid in investigating the existing abuses, by which much good might be effected. The liberal inhabitants of the town and neighbourhood would, I am sure, come forward to second any movement for preservation, if not restoration. Some considerate influence within the last few years has very creditably restored some of the fine buttresses, and arrested the effects of the pressure of the great roof under which the north wall was bulging forward, and threatening to fall prostrate for a good third of its space, and if the accident had happened, total ruin would have been the consequence.

\section{LLANDEAU CHURCH, BRECKNOCKSHIRE.}

THIs very old and remarkable church is situated about two miles to the north-east of Brecon, in a most picturesque village. It was originally the residence of the Bishops of St. David's, and the name is said to be an abbreviation of Llandewi, or St. David's. Giraldus Cambrensis resided in the castle here; and the parish, there is reason to believe, formed a portion of the parish of St. David's, or PlewyDewi, in Brecknockshire. A chapel of ease existed here in which the Archdeacon of Brecon officiated, receiving tithes, and it is supposed to have been the mother church to the Priory of Dominican or Friars' preachers, now called Christ's College (the remains of which have been already noticed), before it was removed to Brecon. A small portion of the castle exists, and a considerable part of the wall, in which are some remains of an early English door, deserving of notice, and an arched fountain, apparently of Norman date, affording a supply on both sides of the wall, for the convenience of the villagers as well as of the inmates of the castle: this is still in use, and the water is of excellent purity. The Church is dedicated to St. David, and comprises a nave, rebuilt barbarously with brick, a chancel, and two transepts, over which a finely-proportioned Norman tower rises. The north transept has a peculiar feature, being lighted only by a long window splaying inwards, about two inches in width, like an oilet hole, and admitting only sufficient light to allow of gaining the foot of a staircase, a very ponderous con- 
struction, serving as a buttress to one angle of the tower, and by which access is gained to the upper story in the tower. This chancel bears the same name as that of the Priory church at Brecon,-_ "Capel y cochiaid." The chancel is in its primitive state, and very rude. It is lighted in its east end by three lancet lights, which splay inward very widely. It has two windows on the north and south sides, with the addition of a very early door on the south, and an Early English stone bench on each side of the door, running east and west. Llandeau Church has no buttresses, but the lower portion of the wall splays outwards as it approaches the foundation, and thus acts the part of one. It is to be regretted that the chancel is used as a burial-place for the poor of Llandeau, as also by the inhabitants of the parish on the other side of the Usk, at Christ's College, which, being extra-parochial, and belonging to Llandeau (its mother church), they claim a right to carry their dead thither, their ancestors having been for ages buried at that place. It may certainly seem natural that they should wish to mingle their dust with that of many generations of their forefathers, and that their bodies should rest together at their ancient mother church of Llandeau.

I have not taken any opportunity of mentioning the beautiful scenery, the site of these remains, which I have attempted to describe and illustrate by the accompanying sketches. Roman remains are very common, and a Roman road crosses the Usk a very short distance above Brecon. Attached, as I was, to the scenery and antiquities of the place, my partiality for it was much enhanced by the kindness and hospitality of numerous residents, amongst whom I cannot resist mentioning my good friend, Mr. John Powell, to whom I owe much for his frequent assistance in my Welsh researches, and the prompt and able manner in which he has since communicated with me on matters connected with the antiquities at Brecon.

H. S. DAVIS, Major, 52nd Regt. Lt. Inf.

The Central Commitree desire to express their acknowledgment of the kind liberality on the part of the Author of the foregoing Notices, in presenting to the Institute the chief part of the Illustrations by which they are accompanied, and in placing at their disposal the very interesting series of drawings, the fruits of his researches in South Wales. 